\title{
Technetium-99m-labeled Recombinant Tissue Plasminogen Activator for the Imaging of Emboli In Vivo
}

\author{
Akihiro TAKAHASHI, Kazuo ITOH*, Eriko TSUKAMOTO*, \\ Masayori FURUdATE*, Hiroyasu KAMIYAMA and Hiroshi ABE \\ Departments of Neurosurgery and ${ }^{*}$ Nuclear Medicine, \\ Hokkaido University School of Medicine, Sapporo
}

\begin{abstract}
Tissue-type plasminogen activator (t-PA) effectively lyses active thrombus by direct action. Recombinant t-PA (rt-PA) was labeled with technetium-99m $\left({ }^{99 \mathrm{~m}} \mathrm{Tc}\right)$ to investigate the in vivo binding to fibrin clots in a feline cerebral embolism model created by insertion of an artificial fibrin clot within the carotid artery. ${ }^{99 \mathrm{~m}} \mathrm{Tc}$-rt-PA administered intravenously provided clearer imaging of clots after priming with cold rt-PA, with uptake peaking 5-10 minutes after the injection. ${ }^{99 m}$ Tc-labeled human serum albumin was not retained at clot sites. Systemically administered ${ }^{99 \mathrm{~m}} \mathrm{Tc}-\mathrm{rt}-\mathrm{PA}$ binds to fibrin clots within carotid arteries in our feline model. Our results suggest that the interaction of intrinsic plasminogen activator inhibitors with extrinsically administered rt-PA may regulate the demonstration of a clot, although the precise mechanism is unclear.
\end{abstract}

Key words: recombinant tissue-type plasminogen activator, technetium, thrombus imaging, cerebral embolism

\section{Introduction}

The development of intravascular surgery and new fibrinolytic agents has recently allowed the aggressive treatment of acute embolic occlusion of cerebral arteries. ${ }^{8,11,19)}$ An important indication for revascularization is differentiation between atherosclerotic thrombotic occlusion (inactive thrombus requiring thrombolytic therapy) and embolic occlusions (active thrombus). However, this is not easy by either clinical or histological studies. ${ }^{18)}$

Recombinant tissue-type plasminogen activator (rt-PA) is a new type of fibrinolytic agent ${ }^{7,9)}$ that can restore the patency of vessels occluded by thromboembolism, even when administered intravenously. ${ }^{12,13,16,17)}$ Tissue-type plasminogen activator (t-PA) has a high affinity for fibrin and rapid blood clearance, so rt-PA labeled with iodine-131, ${ }^{15}$ indium$111,{ }^{3)}$ and technetium-99m $\left({ }^{99 m} \mathrm{Tc}\right)^{1,4)}$ has been used to try to diagnose thrombosis noninvasively. We previously reported a labeling procedure for ${ }^{99 \mathrm{~m}} \mathrm{Tc}$-rt-

Received September 29, 1992; Accepted November 20,1992
PA, its stability, high affinity for fibrin in vitro, and in vivo distribution in control and inferior vena cava thrombus-bearing rats. ${ }^{4,14)}$

This study investigated whether systemically injected ${ }^{99 \mathrm{~m}}$ Tc-rt-PA binds to fibrin clots within carotid arteries in a feline model and the usefulness for the noninvasive diagnosis of cerebral embolism.

\section{Materials and Methods}

rt-PA (SM-9527, lot No. p-113; Sumitomo Chemical Co., Osaka) consisted of a double polypeptide chain with a molecular weight of about 57,000 as determined by electrophoresis. The pure rt-PA used for radiolabeling was dissolved in $0.7 \%$ normal saline containing only $0.01 \%$ Tween 80 , adjusted to $\mathrm{pH} 3$ with hydrochloric acid, and frozen for storage. The protein concentration was $18 \mathrm{mg} / \mathrm{ml}$, and the specific activity $7.82 \times 10^{6} \mathrm{IU} / \mathrm{mg}$.

After melting at room temperature, $0.078 \mathrm{ml}$ $(1.38 \mathrm{mg})$ of rt-PA was pipetted into a plastic tube, and $0.010 \mathrm{ml}(0.001 \mu \mathrm{mol}$ stannous ion) of a commercially available stannous solution (containing 1 $\mu \mathrm{mol} / \mathrm{ml}$ of stannous ion at $\mathrm{pH} \mathrm{3}$; Nihon Medi- 
Physics Co., Osaka) used in ${ }^{99 m} \mathrm{Tc}$ liver imaging was added. After gently stirring for 5 minutes, $0.1 \mathrm{ml}$ of freshly eluted ${ }^{99 \mathrm{~m}} \mathrm{Tc}$ pertechnetate was added, followed by incubation for 15 minutes at room temperature with occasional gentle agitation. The precise qualities of rt-PA and the stability of labeled materials were described previously. ${ }^{4)}$ Radiolabeling efficacy was checked at each use by paper chromatography.

Fibrin cylinders were produced by placing Beriplast P (Behringwerke AG Therapeutics, Marburg, Germany), a kit containing human fibrinogen $(120 \mathrm{mg})$, aprotinin $(1500 \mathrm{Kallikrein}$-inhibitorEinheit), $\mathrm{CaCl}_{2}(22 \mathrm{mg}$ ), and thrombin (450 National Institute of Health Unit), into a polyethylene tube (internal diameter $0.90 \mathrm{~mm}$ ). After incubation at $37^{\circ} \mathrm{C}$ for 24 hours, the tube was cut into $7-\mathrm{mm}$ lengths, and the Beriplast $P$ (which had formed a cylinder within the tube) was removed. Each cylinder was provided with a surgical $10-0$ nylon thread, for use in anchoring inside the vessel after insertion.

Twenty-six adult mongrel cats (mean weight 3.2 $\mathrm{kg})$ were anesthetized with ketamine $\mathrm{HCl}(30 \mathrm{mg} / \mathrm{kg}$ intramuscularly) and atropine sulfate $(0.2 \mathrm{mg}$ intramuscularly), and intubated. Supplemental doses of ketamine were administered as needed. The right common carotid artery (CCA) was isolated via a 3-4 $\mathrm{cm}$ midline incision in the lower neck. Temporary vascular clips were applied to the CCA proximally and distally. Microarteriotomy was then performed, and after rinsing the lumen with normal saline, a fibrin cylinder was inserted. The vessel was then repaired with 10-0 nylon thread and the two vascular clips were removed. When the blood flow through the CCA was restored, the fibrin cylinder became
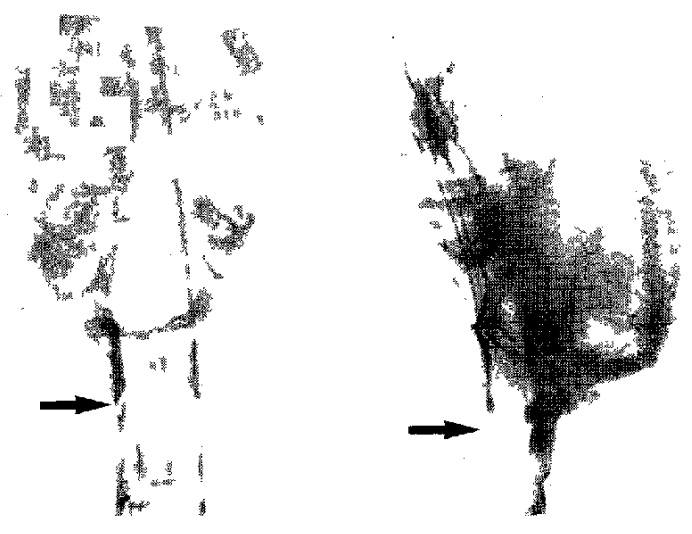

Fig. 1 Right carotid angiograms, showing the fibrin cylinder (arrow) trapped in the vicinity of the carotid bifurcation, acting like a "flying kite." trapped in the vicinity of the carotid bifurcation, thus acting like a "flying kite" (Fig. 1).

${ }^{99 \mathrm{~m}} \mathrm{Tc}-\mathrm{rt}-\mathrm{PA}$ was injected via a peripheral vein $1-2$ hours after preparation of the feline model. In 12 cats of Group 1, $1.0 \mathrm{mg} / \mathrm{kg}$ of ${ }^{99 \mathrm{~m}} \mathrm{Tc}-\mathrm{rt}-\mathrm{PA}(0.1 \mathrm{mg} /$ $\mathrm{ml}$ of $\mathrm{rt}-\mathrm{PA}, 35 \mathrm{MBq} / \mathrm{ml}$ of ${ }^{99 \mathrm{~m}} \mathrm{Tc}$ ) was infused over 60 seconds. In 12 Group 2 cats, $0.5 \mathrm{mg} / \mathrm{kg}$ of cold $\mathrm{rt}$ PA $(0.1 \mathrm{mg} / \mathrm{ml})$ was infused over 30 seconds, followed by infusion of $1.0 \mathrm{mg} / \mathrm{kg}$ of ${ }^{99 \mathrm{~m}} \mathrm{Tc}-\mathrm{rt}-\mathrm{PA}$ over 60 seconds. In two Group 3 cats, ${ }^{99 \mathrm{~m}} \mathrm{Tc}$-labeled human serum albumin was used as a control. Serial images using a gamma camera (GCA-601E; Toshiba, Tokyo) were obtained until 20 minutes after the completion of infusion in four Group 1, four Group 2, and two Group 3 cats. Thrombus-related activity was visually classified into three grades according to intensity and laterality of hot spots. Five Group 1 and five Group 2 animals were sacrificed to calculate the labeled agent uptake 10 minutes after injection. Arterial blood and fibrin cylinders were collected and weighed, and radioactivity measured using a wellscintillation counter (ANSR Abbott Lab., Chicago, Mich., U.S.A.). Results were expressed as percent injected dose per gram tissue. The clot-to-blood ratio was also calculated from the tissue concentration.

An arterial catheter was placed in the left CCA, and 2-ml blood samples collected in polypropylene tubes containing citric acid. Blood was obtained before rt-PA infusion, immediately after ${ }^{99 m} \mathrm{Tc}$-rt-PA infusion, and at 1-minute intervals for 5 minutes, and thereafter at 5-minute intervals from three cats in Group 1. Blood was obtained before rt-PA infusion, immediately after cold rt-PA infusion, and after ${ }^{99 \mathrm{~m}} \mathrm{Tc}$-rt-PA infusion, then at 1 -minute intervals for 5 minutes, and thereafter at 5-minute intervals from three cats in Group 2. All blood samples were centrifuged at $4^{\circ} \mathrm{C}$ and $3000 \mathrm{~g}$ for 5 minutes. The separated serum was stored at $-80^{\circ} \mathrm{C}$ for determination of intrinsic plasminogen activator inhibitor1 (PAI-1) levels using a commercially available sandwich enzyme-linked immunosorbent assay kit (Biopool IMULYSE ${ }^{\text {TM }}$ PAI-1; Biopool Hamilton Co., Ontario, Canada).

Statistical analyses were performed using Student's $\mathbf{t}$-test. Results are presented as the mean \pm SD unless otherwise noted.

\section{Results}

The labeling stabilities of diluted ${ }^{99 \mathrm{~m}} \mathrm{Tc}-\mathrm{rt}-\mathrm{PA}$ at injection were $81.9-89.3 \%$ (mean $84.6 \pm 3.4 \%$ ).

Table 1 summarizes the intensities of thrombusrelated activity. Serial images of illustrative cases from Groups 1, 2, and 3 are shown in Figs. 2, 3, and 
Table 1 Results of thrombus imaging

\begin{tabular}{cc}
\hline Case No. & Thrombus-related activity \\
\cline { 2 - 2 } Group $1-1^{* *}$ & \pm \\
$1-2$ & \pm \\
$1-3$ & - \\
$1-4$ & - \\
$2-1^{* *}$ & + \\
$2-2$ & + \\
$2-3$ & \pm \\
$2-4$ & - \\
$3-1^{* *}$ & - \\
$3-2$ & - \\
\hline
\end{tabular}

*Intensity of hot spot: - , negative; \pm , faintly visible; + , moderately visible. ${ }^{* *}$ Illustrative cases shown in Figs. 2, 3, and 4, respectively.

Table 2 Tissue concentration of $99 \mathrm{~m}$ Tc-rt-PA 10 minutes after injection in a feline model

\begin{tabular}{lcc}
\cline { 2 - 3 } \multicolumn{1}{c}{ Organ } & Group 1 $(\mathrm{n}=5)$ & Group 2 (n=5) \\
Clot & $-0.49 \pm 0.12$ & $0.61 \pm 0.19$ \\
Blood & $0.45 \pm 0.10$ & $0.40 \pm 0.16$ \\
Clot/blood ratio & $1.06 \pm 0.04^{*}$ & $1.64 \pm 0.41^{*}$
\end{tabular}

Values are expressed as mean $\pm \mathrm{SD}$, and concentrations in \% dose $/ \mathrm{g}$ tissue. *Statistically significant $(\mathrm{p}=0.016)$.

4, respectively. In Group 1, slightly increased ${ }^{99 m} \mathrm{Tc}-$ rt-PA radioactivity was detected in the vicinity of the right carotid bifurcation in two cats, but no increase in the other two. In Group 2, the radioactivity level was considerably higher in two cats than in Group 1; one cat showed a slight increase of radioactivity, and other no increase. These findings suggested that ${ }^{99 m}$ Tc-rt-PA accumulated in the fibrin cylinders in Group 1 and 2 cats. The peak radioactivity was observed at 5-10 minutes and then decreased. No increase in radioactivity was detected in the Group 3 animals.

In Group 1, the fibrin cylinders with fresh thrombi formed in the surface weighed $2-7 \mathrm{mg}$ (mean $2.7 \mathrm{mg}$ ), and in Group 2, 2-3 mg $(2.5 \mathrm{mg})$. The concentrations of ${ }^{99 \mathrm{~m}} \mathrm{Tc}$-rt-PA normalized to $\%$ dose/g in clots (fibrin cylinders) and blood, and the clot/blood ratio in both groups are shown in Table 2. Clot/blood ratio in Group 2 was significantly higher than in Group $1(\mathrm{p}=0.016)$.

Serum concentrations of PAI-1 in cats were below the measurable level using the kit designed for humans.

\section{Discussion}

This study showed that fibrin clots within the cat carotid artery model were visualized by serial imaging of the clot-associated radioactivity due to systemically administered ${ }^{99 \mathrm{~m}} \mathrm{Tc}$-rt-PA.

Deboer $e t a l .{ }^{11}$ found that thrombus imaging was difficult after systemic injection of ${ }^{99 \mathrm{~m}} \mathrm{Tc}-\mathrm{rt}-\mathrm{PA}$, but was possible with local injection. Itoh et $\mathrm{al}^{4)}$ and Tsukamoto ${ }^{14)}$ succeeded in labeling rt-PA with ${ }^{99 \mathrm{~m}} \mathrm{Tc}$ by the stannous reduction method, and showed that ${ }^{99 m}$ Tc-rt-PA had a high affinity for fibrin in vitro, and that ${ }^{99 m}$ Tc-rt-PA administered intravenously accumulated in the inferior vena cava thrombi in the rat. The images, however, were not as clear as expected, possibly because: 1) ${ }^{99 \mathrm{~m}} \mathrm{Tc}$-rt-PA only binds to the surface of a thrombus, 2) thrombolysis causes ${ }^{99 m}$ Tc-rt-PA bound to fibrin to flow away from the thrombus in a vessel, 3) extrinsic t-PA binds with PAI-1 (an immediate-type inhibitor) and forms complexes which are probably incapable of binding to fibrin, and 4) species differences among animals. ${ }^{2,5)}$ In this study, we produced fibrin cylinders containing aprotinin, an anti-thrombolytic agent, for use as model emboli. We inserted these model emboli into the carotid artery, and anchored them with sutures ("kite flying") to increase the surface area in contact with the blood stream, although such a "flying kite". like embolus is not observed clinically. The ${ }^{99_{\mathrm{m}} \mathrm{Tc}-\mathrm{rt}-}$ PA dose of $1.0 \mathrm{mg} / \mathrm{kg}$ was chosen, because in our experience $^{4,14)}$ a larger dosage of labeled rt-PA than clinically administered to humans is needed to obtain thrombus images in animals.

When hot rt-PA alone was used, the images obtained were unclear. ${ }^{14)}$ However, the accumulation became clearer by first priming with cold rt-PA, then administering hot It-PA. The hot images of the clots may overlap with the thyroid gland or be a blood pool, as the activity in the figures is larger than a clot within a carotid artery, and the thyroid gland is located similarly in the neck. However, the larger size of hot images can be explained by the blooming effect $^{6}$ in scintigraphy, while thyroid-related activity due to the accumulation of free ${ }^{99 m} \mathrm{Tc}$ usually remains unchanged with time as in Fig. 4. We believe that the hot images reflect fibrin clots. The clot/blood radioactivity ratio was significantly increased in the modified method, possibly due to interaction between intrinsic plasminogen activator inhibitors (PAIs) and extrinsically administered rt-PA. ${ }^{(0)}$ Cold rt-PA injected first may complex with PAI, so subsequently injected ${ }^{99 \mathrm{~m}} \mathrm{Tc}$-rt-PA remains in the free state, is transported, and binds to the fibrin block. In addition, cold rt-PA may lyse secondary thrombus 


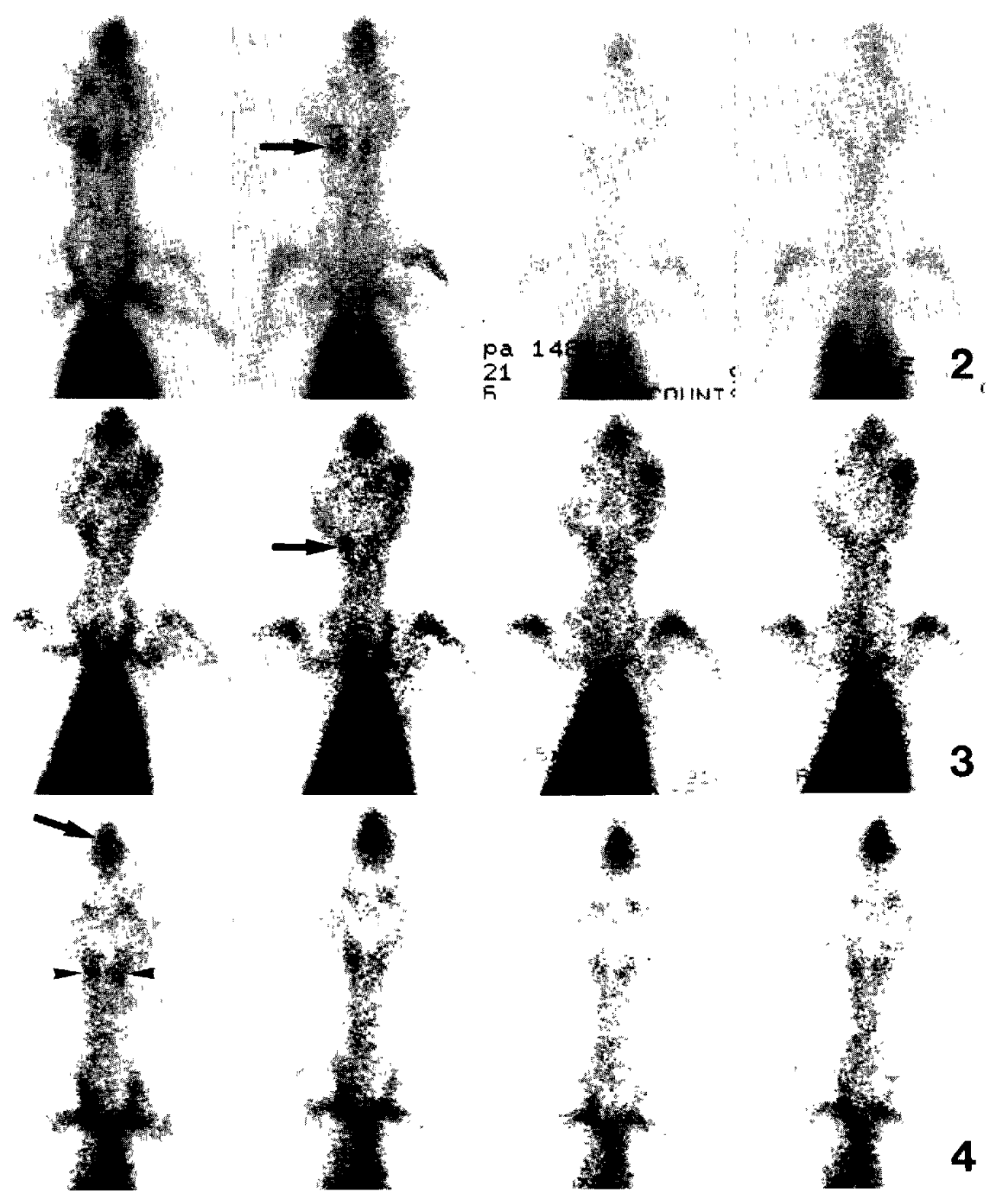

Fig. 2 Sequential images of a Group 1 cat taken at 5 -minute intervals after administration of $1.0 \mathrm{mg} / \mathrm{kg}$ of ${ }^{99 m}$ Tc-rt-PA. Positive uptake (arrow) corresponding to the fibrin cylinder is seen in the right side of the neck.

Fig. 3 Sequential images of a Group 2 cat taken at 5 -minute intervals after administration of $0.5 \mathrm{mg} / \mathrm{kg}$ of cold rt-PA and $1.0 \mathrm{mg} / \mathrm{kg}$ of ${ }^{99 \mathrm{~m}} \mathrm{Tc}-\mathrm{rt}-\mathrm{PA}$. Radioactivity corresponding to the fibrin cylinder (arrow) increases to higher levels than in Group 1.

Fig. 4 Sequential images of a Group 3 cat taken at 5 -minute intervals after injection of ${ }^{99 m} \mathrm{Tc}$-labeled human serum albumin. Persistent visualization of both thyroid glands (arrowheads) and a region of the nasal cavity (arrow) suggest accumulation of free ${ }^{99 m} \mathrm{Tc}$ pertechnetate. No focal uptake in the fibrin cylinder is shown.

formed around the fibrin cylinder, facilitating ${ }^{99 \mathrm{~m}} \mathrm{Tc}-$ rt-PA contact with the cylinder. We attempted to measure changes in PAI-1 after the injection of cold and hot rt-PA to identify any interaction with PAI, but the activity of PAI-1 could not be measured in our cat model.

Local administration of ${ }^{99 \mathrm{~m}} \mathrm{Tc}$-rt-PA through the carotid artery at angiography is an attractive pro- 
cedure for enhancement of accumulation. However, local injection of hot rt-PA into a totally occluded carotid artery has two possible diagnostic evaluations: uptake by clots as true positive and blood pooling as false positive. The absence of blood flow at the arterial occlusion may cause pooling to resemble true uptake by an active thrombus. This may limit the practical use of local infusion of ${ }^{99 m} \mathrm{Tc}-\mathrm{rt}-\mathrm{PA}$ in occlusive cerebral arterial disease.

\section{Acknowledgments}

We thank Sumitomo Pharmacy Co. for its generous supply of rt-PA. We also thank Mr. M. Kawatake and technicians of the Nuclear Medicine Division of Hokkaido University Hospital for assistance with the study.

\section{References}

1) Deboer AC, Pauluama JH, Cox PH, Collen D: Tc$99 \mathrm{~m}$ labeled plasminogen activator (PA) for the diagnosis of deep vein thrombosis. Thromb Haemost 50: 159, 1983 (abstract)

2) Häggroth L, Mattson $\mathrm{CH}$, Friberg J: Inhibition of the human tissue plasminogen activator in plasma from different species. Thromb Res 33: 583-594, 1984

3) Hnatowich DJ, Virzi F, Doherty PW, Wilson J, Rosa $\mathrm{J}$, Ansell JE: Characterization of indium-111 labeled recombinant tissue plasminogen activator for the imaging of thrombi. Eur J Nucl Med 13: 467-473, 1987

4) Itoh $H$, Tsukamoto $E$, Nishibe $T$, Sakurama $S$, Ieka M, Tanabe T, Furudate M: Tc-99m labeled tissuetype plasminogen activator. Preparation, stability and preliminary imaging of thrombus-bearing rats. Ann Nucl Med 5: 59-64, 1991

5) Korninger $C$, Collen D: Studies on the specific fibrinolytic effect of human extrinsic (tissue-type) plasminogen activator in human blood and in various animal species in vitro. Thromb Haemost 46: 561565,1981

6) Lisbona R, Wexler MJ, Novales-Diaz JA: Misleading appearance of biliary dilatation. $J$ Can Assoc Radiol 31: 67-68, 1980

7) Matsuo O, Rikken DC, Collen D: Thrombolysis by human tissue plasminogen activator and urokinase in rabbits with experimental pulmonary embolus. Nature 291: 590-591, 1981

8) Mori E, Tabuchi M, Yoshida T, Yamadori A: Intracarotid urokinase with thromboembolic occlusion of the middle cerebral artery. Stroke 19; 802-812, 1988

9) Rijken DC, Hoylaerts M, Collen D: Fibrinolytic properties of one-chain and two-chain human extrinsic (tissue-type) plasminogen activator. J Biol Chem 257: $2920-2925,1981$
10) Sprengers ED, Kluft C: Plasminogen activator inhibitors. Blood 69: 381-387, 1987

11) Theron J, Courtheoux P, Casasco A, Alachkar F, Notari F, Maiza D: Local intraarterial fibrinolysis in the carotid territory. $A J N R$ 10: 753-765, 1989

12) The TIMI Study Group: The thrombosis in myocardial infarction (TIMI) trial: Phase I findings. New Engl J Med 312: 932-936, 1985

13) Topol EJ, George BS, Kereiakes DJ, Stump DC, Candela RJ, Abbottrmith CW, Aronson L, Pickel A, Boswick JM, Lee KL, Ellis SG, Califf RM (TAMI Study Group): A randomized controlled trial of intravenous tissue plasminogen activator and early intravenous heparin in acute myocardial infarction. Circulation 79: 281-286, 1989

14) Tsukamoto $\mathrm{E}$ : In vivo distribution of $\mathrm{Tc}-99 \mathrm{~m}$ labeled recombinant tissue type plasminogen activator in control and thrombus-bearing rats. Ann NuCl Med 6: $177-184,1992$

15) Uehara A, Isaka Y, Etani H, Kimura K, Yoneda S, Kamada T, Kozuka T, Nobuhara M: Binding of ${ }^{131} \mathrm{I}-$ labeled tissue-type plasminogen activator on de-endothelialized lesions in rabbits. Nuklearmedizin 26: 224-228, 1987

16) Verstraete $M$, Bory $M$, Collen $D$, Erbel R, Lennane RJ, Mathey D, Michaels HR, Schartl M, Uebis R, Bernard R, Brower RW, Debond DP, Uhmann W, Lubsen J, Meyer J, Rutsch W, Schmidt W, Vonessen $R$ : Randomized trial of intravenous recombinant tissue-type plasminogen activator versus intravenous streptokinase in acute myocardial infarction. Lancet 13: $842-847,1985$

17) Williams DO, Borer J, Braunwald E, Chesebro JH, Cohen LS, Dalen J, Dodge HT, Francis CK, Knatterud $G$, Ludbrook $P$, Markis JE, Mueller $H$, Desvigen-Nickens P, Passamini ER, Powers ER, Rao AK, Roberts R, Ross A, Ryan TJ, Sobel BE, Winniford M, Zarert B: Intravenous recombinant tissuetype plasminogen activator in patients with acute myocardial infarction: A report from the NHLBI thrombosis in myocardial infarction trial. Circulation 73: $338-348,1986$

18) Yamaguchi $T$, Minematsu $K$, Choki J, Ikeda $M$ : Clinical and neuroradiological analysis of thrombotic and embolic cerebral infarction. Jpn Circ $J$ 48: 50-58, 1984

19) Zeumer H, Hödgen R, Ferbert A, Ringelstein EB: Local intraarterial fibrinolytic therapy in inaccessible internal carotid occlusion. Neuroradiology 26: $315-$ 317,1984

Address reprint requests to: A. Takahashi, M.D., Department of Neurosurgery, Hokkaido University School of Medicine, North-15, West-7, Kita-ku, Sapporo 060, Japan. 